\title{
Pengembangan Kapasitas Pengasuh dan Orang Tua Daycare Rumah Bahagia Surabaya
}

\author{
${ }^{1}$ Reneta Kristiani, ${ }^{2}$ Penny Handayani, ${ }^{3}$ Roelofje Wolting, ${ }^{4}$ Aurelia Ardani, ${ }^{5}$ David Nicholas \\ Franztius \\ 1, 2, 4, 5 Fakultas Psikologi UNIKA Atma Jaya, \\ ${ }^{3}$ Pusat Pemberdayaan Masyarakat UNIKA Atma Jaya \\ Email: ${ }^{1}$ reneta.kristiani@atmajaya.ac.id, ${ }^{2}$ penny.handayani@atmajaya.ac.id, ${ }^{3}$ roelie.wolting@gmail.com, \\ ${ }^{4}$ aurelia.201707000086@student.atmajaya.ac.id, ${ }^{5}$ david.201707000030@student.atmajaya.ac.id
}

\section{Article Info}

Submitted: 16 October 2020

Revised: 23 December 2020

Accepted: 30 December 2020

Published: 21 April 2021

Keywords: special needs children, parenting, daycare.
Kata kunci: anak berkebutuhan khusus, pengasuhan, daycare

\section{Abstract}

Daycare Rumah Bahagia (DCRB) is a service for laborer parents so their children can get optimal fulfillment of their rights while parents are working in the factory. Unfortunately, DCRB did not have caregivers who are competent in special needs children. The last education of caregivers was mostly high school. None of them came from special needs education. Most of parents had lack understanding about their special needs children. They also could not afford health and psychological services, assessments, and interventions for special needs children due to their financial condition. Due to that reason, the caregivers and parents needed capacity-building activity. These capacity-building activities directly targeted parents and caregivers, furthermore indirectly for the welfare of children. Methods of capacity building activities were: 1) individual counseling for parents of special needs children; 2) seminars for all parents and caregivers; 3) provision for caregivers on how to stimulate and handle special needs children. Tools were also provided to assess special needs children. The results of these activities were the parents and caregivers got better understanding of their special needs children. Caregivers are now able to monitor and perform early detection for special needs children and build a suitable curriculum and learning program based on the needs of every child. Suggestions for the next community services activities should be to analyze the needs of daycare management and provide individual learning program curriculum for special needs children as well as provide more in-depth training to daycare managers and caregivers on inclusive education.
Abstrak
Daycare Rumah Bahagia (DCRB) memberikan layanan bagi anak-anak buruh agar mendapatkan pemenuhan hak pengasuhan yang optimal selama orang tua mereka bekerja di pabrik. Namun hingga saat ini 
DCRB belum memiliki pengasuh yang kompeten untuk Anak-Anak Berkebutuhan Khusus (ABK). Pendidikan terakhir sebagian besar pengasuh adalah SMA. Demikian pula dengan orang tua ABK yang kurang memahami kondisi anak mereka karena sulitnya mendapatkan akses layanan kesehatan maupun psikologis, serta terkendala masalah biaya. Oleh karena itu, kegiatan pengembangan kapasitas dilakukan untuk para pengasuh dan orang tua DCRB. Tujuannya agar pengasuh dan orang tua dapat lebih memahami anak-anak berkebutuhan khusus. Kegiatan pengembangan kapasitas ini menyasar langsung orang tua dan pengasuh serta secara tidak langsung demi kesejahteraan anak-anak. Metode kegiatan pengembangan kapasitas: 1) kegiatan konseling individual untuk orang tua; 2) seminar bagi seluruh orang tua dan pengasuh; dan 3) pembekalan untuk pengasuh mengenai cara stimulasi dan penanganan anak berkebutuhan khusus. Selain itu, diberikan juga alat bantu untuk memetakan anak berkebutuhan khusus. Hasil dari kegiatan ini adalah meningkatnya pemahaman orang tua dan pengasuh mengenai perkembangan dan pendidikan anak berkebutuhan khusus. Orang tua dan pengasuh juga semakin terampil dalam mengasuh dan memberikan stimulasi untuk anak berkebutuhan khusus. Pengasuh kini mampu memantau perkembangan anak dan melakukan deteksi dini ABK sehingga dapat menyusun kurikulum dan program pembelajaran yang sesuai dengan kebutuhan setiap anak. Saran bagi kegiatan pengabdian masyarakat berikutnya agar melakukan analisis kebutuhan pengelolaan daycare dan memberikan pelatihan program pembelajaran individual untuk anak berkebutuhan khusus serta memberikan pelatihan yang lebih mendalam kepada pengelola daycare dan pengasuh mengenai pendidikan inklusi.

\section{PENDAHULUAN}

Daycare Rumah Bahagia (DCRB) merupakan layanan bagi anak-anak buruh yang diinisiasi oleh Institut Solidaritas Buruh Surabaya (ISBS). Tujuannya agar anak-anak buruh tetap mendapatkan pemenuhan hak anak, terutama hak atas pengasuhan yang optimal selama orangtua mereka bekerja di pabrik. Layanan yang diberikan termasuk pengasuhan anak yang menitikberatkan pada kesehatan fisik dan mental, karakter positif anak, hubungan/ relasi sosial, kepedulian terhadap lingkungan, kemampuan berbahasa, aspek kognitif, serta kreativitas dan seni. Daycare Rumah Bahagia ini terletak di Gang Sekolahan No. 22, Jalan Klakahrejo, Kelurahan Kandangan, Kecamatan Benowo, Surabaya. Daycare Rumah Bahagia ini di bawah naungan Yayasan Rumah Anak Bahagia yang memiliki visi menjadi rumah bermain, berekspresi, dan berkreasi bagi anak untuk mencapai pribadi berkarakter dan berbudi pekerti luhur. Misi dari Yayasan Rumah Anak Bahagia adalah mewujudkan kepribadian anak yang cinta Tuhan dan sesama, menambahkan karakter positif pada anak, membangun kecerdasan, kreativitas, dan kemandirian anak.

Daycare Rumah Bahagia telah berdiri selama 4 tahun dan mulai melakukan perbaikan kualitas layanan sejak tahun 2017. Jumlah anak yang diasuh saat ini adalah 17 orang anak dengan rentang usia dari 2 hingga 9 tahun. Terdapat dua kelas berdasarkan kelompok usia, yaitu kelas Kelompok Bermain (KB) usia 2 - 4 tahun (8 anak) dan kelas Taman Kanak-Kanak (TK) yang terdiri dari gabungan anak usia 5-7 tahun (7 anak) dengan kelompok usia $>7$ tahun ( 2 anak). Daycare Rumah Bahagia telah melaksanakan kegiatan belajar dan bermain berdasarkan rencana pengajaran harian yang berpusat pada anak (child-centered) dan memperhatikan tahapan perkembangan berdasarkan usia anak. Di kelas KB, terdapat anak yang memiliki 
kebutuhan khusus, yaitu ASD (Autism Spectrum Disorder), keterlambatan bicara, juga kebutuhan khusus ganda (intellectual disabilities dan tuli). Di kelas TK, ada seorang anak yang memiliki tingkat intelegensi di bawah rata-rata dan pernah mengalami pengalaman traumatis akibat perselisihan kedua orang tuanya. Ada pula anak dengan masalah perilaku yang sering membantah, melanggar aturan, mengganggu teman-temannya, dan lain-lain.

Menurut Undang-Undang Nomor 8 Tahun 2016 tentang penyandang disabilitas, pengertian penyandang disabilitas atau anak dengan kebutuhan khusus adalah setiap orang yang mengalami keterbatasan fisik, intelektual, mental, dan/atau sensorik dalam jangka waktu lama yang dalam berinteraksi dengan lingkungan dapat mengalami hambatan dan kesulitan untuk berpartisipasi secara penuh dan efektif dengan warga negara lainnya berdasarkan kesamaan hak (Kemenkes, 2018). Anak Berkebutuhan Khusus (ABK) atau penyandang disabilitas tersebut meliputi gangguan penglihatan (tuna netra), gangguan pendengaran (tuli), gangguan komunikasi dan bicara (tuna wicara), gangguan kognitif atau kecerdasan (tuna grahita), gangguan gerak (tuna daksa), gangguan emosi dan perilaku (tuna laras), dan gangguan belajar (kesulitan belajar). Ragam ABK ini dapat dialami secara tunggal, ganda, atau multi dalam jangka waktu lama yang ditetapkan oleh tenaga medis sesuai dengan ketentuan peraturan perundangundangan (Kemenkes, 2018).

Permasalahan di Daycare Rumah Bahagia yaitu hingga saat ini belum memiliki pengasuh yang berkompetensi dalam mengasuh dan mendampingi tumbuh kembang anak dengan kebutuhan khusus (ABK). Pendidikan terakhir pengasuh sebagian besar adalah SMA dan hanya ada satu yang mengenyam pendidikan keguruan jurusan seni. Dengan keterbatasan yang ada, Daycare Rumah Bahagia tetap menerima ABK karena didasari pada komitmen untuk memberikan perlindungan keamanan kepada anak-anak buruh selama kedua orang tua mereka bekerja. Oleh sebab itu, adanya kebutuhan pengembangan kapasitas bagi para pengasuh terutama dalam penanganan ABK. Pengembangan kapasitas diartikan sebagai upaya memperkuat kapasitas individu, kelompok atau organisasi yang dicerminkan melalui pengembangan kemampuan, keterampilan, potensi, dan bakat serta penguasaan kompetensi sehingga individu, kelompok atau organisasi dapat bertahan dan mampu mengatasi tantangan perubahan yang terjadi secara cepat dan tak terduga (Milen, 2004).

Selain untuk para pengasuh, peningkatan kapasitas ini juga ditujukan untuk para orang tua anak berkebutuhan khusus. Sebagian besar orangtua ABK di Daycare Rumah Bahagia kurang memahami kondisi anak dan kebingungan dalam mengasuh $\mathrm{ABK}$, karena kebutuhan anak yang berbeda dari umumnya. Para orang tua kesulitan mendapatkan akses layanan pemeriksaan psikologis maupun pemeriksaan tumbuh kembang anak yang memadai. Beberapa orang tua harus seringkali datang ke Pusat Layanan Tumbuh Kembang Anak. Hal ini menyulitkan mereka karena mereka berprofesi sebagai buruh yang tidak bisa sering izin dari tempat kerja. Selain itu, ada pula layanan terapi yang harus mengeluarkan biaya yang cukup besar dan tidak tercakup dalam BPJS. Akibatnya pemeriksaan dan penanganan ke ABK terhenti di tengah jalan dan tidak tuntas. Ada pula ABK yang seharusnya bersekolah di Sekolah Luar Biasa (SLB), tetapi karena jarak yang cukup jauh dari rumah, akhirnya anak tersebut pun putus sekolah. Anak tersebut hanya dititipkan di Daycare Rumah Bahagia sementara orang tuanya bekerja.

Atas dasar permasalahan tersebut, maka solusi untuk mendukung upaya perbaikan kualitas layanan Daycare Rumah Bahagia adalah dengan mengadakan kegiatan pengembangan kapasitas bagi para pengasuh dan orang tua dalam mendampingi tumbuh kembang Anak Berkebutuhan Khusus (ABK). Kegiatan pengembangan kapasitas tersebut, meliputi kegiatan mentoring, konseling, dan psikoedukasi bagi para pengasuh dan berbentuk diskusi, kunjungan kelas, seminar hari keluarga, dan sebagainya bagi orang tua. Materi yang dibahas dalam program orangtua disesuaikan dengan kebutuhan orang tua yang terkait dengan permasalahan pendidikan, perawatan, dan pengasuhan anak. Fasilitator ahli dalam kegiatan ini adalah psikolog dan terapis untuk anak berkebutuhan khusus, yang memiliki pengalaman untuk mendampingi dan terapi 
anak dengan ASD (Autism Spectrum Disorder), terlambat bicara, tuli, serta anak dengan tingkat kecerdasan rendah.

Tujuan dari program pengembangan ini adalah untuk meningkatkan kapasitas para pengasuh dan orang tua Daycare Rumah Bahagia mengenai anak berkebutuhan khusus. Kementerian Pemberdayaan Perempuan dan Perlindungan Anak (2013) menyatakan pentingnya keberadaan pendampingan anak berkebutuhan khusus bagi proses perlindungan dan tumbuh kembang anak. Oleh karena itu, pengetahuan dan peningkatan kapasitas pendamping, yaitu orang tua, keluarga, dan masyarakat dalam menghadapi anak berkebutuhan khusus sejak dini akan memberikan dampak signifikan dalam merawat, memelihara, mendidik, dan mengembangkan bakat yang dimiliki setiap anak berkebutuhan khusus.

\section{METODE}

Metode pengembangan kapasitas yang digunakan untuk para pengasuh dan orang tua Daycare Rumah Bahagia adalah psikoedukasi. Psikoedukasi merupakan suatu intervensi yang dapat dilakukan pada individu, keluarga, dan kelompok yang fokus pada mendidik peserta mengenai tantangan signifikan dalam hidup, membantu peserta mengembangkan sumbersumber dukungan dan keterampilan untuk menghadapi tantangan tersebut (Walsh, 2010). Kegiatan psikoedukasi yang dilakukan dalam pengabdian masyarakat ini berupa:

a. Konseling individual bagi orang tua ABK di mana setiap orang tua secara bergantian mendapatkan kesempatan untuk konseling dengan psikolog dan terapis untuk berkonsultasi mengenai masalah yang mereka hadapi terkait dengan pengasuhan ABK.

b. Seminar untuk seluruh orang tua dan pengasuh Daycare Rumah Bahagia di mana materi seminar meliputi memberikan pemahaman mengenai perkembangan anak pada umumnya, beragam jenis anak berkebutuhan khusus, pemetaan anak berkebutuhan khusus, pendidikan inklusi, berbagai cara stimulasi untuk mengembangkan potensi dan penanganan perilaku bermasalah anak berkebutuhan khusus, seperti tantrum. Seminar dilakukan dengan cara ceramah interaktif disertai dengan diskusi tanya jawab dan role play di mana fasilitator mencontohkan cara yang tepat dalam memberikan stimulasi pada anak berkebutuhan khusus. Peserta orang tua diberi kesempatan mencoba bermain peran mempraktikkan teknik yang sudah dijelaskan sebelumnya.

c. Pembekalan untuk pengasuh mengenai cara stimulasi dan penanganan anak berkebutuhan khusus dengan menggunakan metode role play di mana pengasuh mengikuti arahan fasilitator untuk memerankan sebuah situasi nyata. Fasilitator memberikan contoh perilaku yang tepat dalam menangani anak. Peserta kemudian mengikuti contoh tersebut. Menurut Chan (2010) role play dapat membantu peserta berlatih dan mencoba berbagai teknik baru. Manfaat role play dapat memberikan wawasan tentang perilaku peserta sendiri dan juga perilaku orang lain (Chan, 2010). Selain role play, fasilitator juga menggunakan metode diskusi. Diskusi merupakan metode yang digunakan untuk meningkatkan percakapan lisan dua arah di antara para peserta. Diskusi bermanfaat untuk meningkatkan pemikiran dan membantu para peserta memahami materi. Diskusi dapat membuat para peserta semakin dekat dan terlibat aktif mengungkapkan pemikirannya. Diskusi dapat membantu peserta memahami pentingnya kemampuan komunikasi (Arends, 2012). Selain itu, pengasuh juga diberikan alat bantu agar dapat memetakan anak berkebutuhan khusus sehingga dapat membuat program individual yang sesuai dengan kebutuhan ABK.

Keseluruhan peserta berjumlah 26 orang, yang terdiri dari 7 pengasuh, 2 pengelola, dan 17 orang tua. Sebagian besar orang tua adalah buruh. Sebagian besar pengasuh berpendidikan SMA dan hanya satu pengasuh yang mengenyam pendidikan keguruan jurusan seni. Sasaran langsungnya adalah:

1. Orang tua

2. Pengasuh 


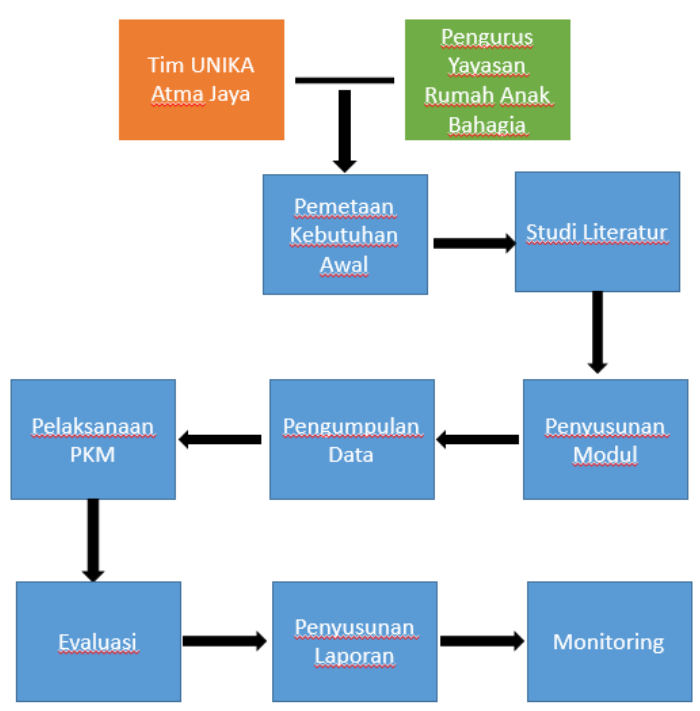

Gambar 1. Diagram Alur Metode PKM.

Sedangkan sasaran tidak langsungnya adalah anak-anak berkebutuhan khusus agar mereka mendapatkan penanganan yang sesuai dan dapat berkembang secara optimal. Fasilitator ahli dalam kegiatan ini adalah psikolog dan terapis untuk anak berkebutuhan khusus, yang memiliki pengalaman untuk mendampingi dan terapi anak dengan ASD (Autism Spectrum Disorder), terlambat bicara, tuli, serta anak dengan tingkat kecerdasan rendah (intellectual disabilities). Pelaksanaan pengembangan kapasitas ini berlangsung dalam waktu 3 hari, dimulai sejak 13 hingga 15 Maret 2020 di Daycare Rumah Bahagia, Surabaya.

Alur persiapan hingga pelaksanaan kegiatan pengembangan kapasitas untuk orang tua dan pengasuh Daycare Rumah Bahagia dapat dilihat pada Gambar 1.

\section{Tahap Persiapan}

1. Pemetaan Kebutuhan Awal

Tim dari UNIKA Atma Jaya bertemu dengan pengurus Yayasan Rumah Anak Bahagia yang juga adalah pengurus ISBS (Institut Solidaritas Buruh Surabaya). Pengurus Yayasan tersebut mengungkapkan kondisi Daycare Rumah Bahagia Surabaya. Berdasarkan hasil diskusi diperoleh informasi kebutuhan dalam pengembangan kapasitas bagi para pengasuh dan orang tua ABK, karena kurangnya pemahaman dan pengalaman mereka dalam mengasuh dan menangani ABK.

\section{Penyusunan Modul}

Tim dari UNIKA Atma Jaya yang terdiri dari psikolog dan terapis melakukan persiapan dengan menyusun modul yang berisi materi tentang dengan $A B K$, deteksi dini $A B K$, cara pengasuhan $A B K$, stimulasi bagi $A B K$, dan seterusnya. Modul terbagi menjadi dua, yaitu modul untuk pengasuh daycare dan modul untuk orang tua. Saat menyusun modul, tim melakukan studi literatur terlebih dahulu. Selain itu, tim juga saling berbagi pengalaman penanganan ABK. Kemudian tim berdiskusi bersama terkait bahan materi serta cara memberikan materi tersebut ke orang tua dan pengasuh. Tim juga berbagi tugas sehingga setiap orang mempersiapkan topik yang diberikan.

\section{Tahap Pelaksanaan}

\section{Observasi}

Kegiatan pengembangan kapasitas diawali dengan melakukan observasi. Observasi dilakukan pada setting natural, yaitu saat anak-anak sedang melakukan kegiatan keseharian mereka di Daycare Rumah Bahagia. Menurut Papalia dan Martorell (2014), dalam observasi di setting natural, tidak ada intervensi sama sekali. Tim mencatat atau merekam apa yang dilihat. Observasi setting natural ini menghasilkan data yang kaya karena dapat menggambarkan perilaku yang muncul sebagaimana adanya.

Selain observasi, tim melakukan wawancara dengan pengasuh Daycare Rumah Bahagia maupun orang tua. Selanjutnyatimmelakukananalisisdokumen ABK yang meliputi formulir pendaftaran yang berisi data diri anak dan orang tua, hasil rapor atau catatan perkembangan anak yang ditulis oleh pengasuh, serta berbagai hasil tes pemeriksaan dari dokter maupun psikolog sebelumnya. Menurut Papalia dan Martorell (2014) pengumpulan data melalui analisis dokumen dan wawancara dapat memberikan informasi penting mengenai riwayat perkembangan kehidupan seseorang.

Pada tahap pengumpulan data ini dibantu oleh mitra, yaitu pengurus ISBS 
yang sekaligus bertindak sebagai pengelola Daycare Rumah Bahagia. Pengurus ISBS yang mengumpulkan pengasuh dan orang tua, baik orang tua $\mathrm{ABK}$ maupun orang tua anak-anak lain di Daycare Rumah Bahagia. Pengurus ISBS juga membantu dalam menyediakan berkas-berkas yang dibutuhkan dalam analisis dokumen. Pengurus ISBS juga menjamin transportasi dan akomodasi bagi tim dari UNIKA Atma Jaya selama berada di Surabaya.

\section{Pelaksanaan}

Kegiatan pengembangan kapasitas ini dilakukan secara:

a. Individual melalui konseling individu ke setiap orang tua yang memiliki ABK.

b. Berkelompok melalui kegiatan psikoedukasi ke kelompok pengasuh dan juga ke kelompok orang tua seluruh anak di Daycare Rumah Bahagia (DCRB).

Kegiatan pengembangan kapasitas ini memberikan materi yang terkait dengan pemahaman tahap perkembangan anak secara umum, pemahaman definisi $\mathrm{ABK}$, ragam $\mathrm{ABK}$, mendorong terciptanya masyarakatinklusif, dan pendidikan inklusif yang memperhatikan keunikan setiap anak. Selain itu, kegiatan ini juga melatih keterampilan para pengasuh dan orang tua agar terampil dalam menangani ABK. Tidak hanya itu, bagi para pengasuh diberikan alat bantu untuk mengukur perkembangan setiap anak agar dapat membuat kurikulum atau Program Pembelajaran Individual (PPI) sehingga dapat tercipta pengasuhan dan pendidikan inklusif.

Peralatan yang digunakan dalam kegiatan pengembangan kapasitas ini adalah:

a. Untuk kegiatan konseling orang tua dilakukan di ruangan tertutup milik kantor pengelola DCRB yang letaknya di belakang serta agak jauh dari kegiatan anak-anak sehingga nyaman untuk konseling.

b. Untuk kegiatan seminar orang tua dan pengasuh dilakukan di ruang bermain anak yang relatif luas di mana para orang tua duduk di tikar menghadap ke dinding di mana materi presentasi ditayangkan melalui LCD. Perlengkapan yang digunakan adalah laptop dan LCD serta buku cerita dan mainan anak sebagai contoh stimulasi saat role play.

c. Untuk kegiatan pembekalan pengasuh dilakukan di ruang bermain anak yang lebih sempit di mana pengasuh duduk di lantai secara melingkar mendengarkan materi dari fasilitator. Perlengkapan yang dipakai adalah beberapa alat permainan dan juga beberapa lembar alat bantu untuk mengukur perkembangan anak serta alat tulis.

Rangkaian pelaksanaan kegiatan pengembangan kapasitas ini adalah:

1) Di hari pertama, yaitu pada hari Jumat, tanggal 13 Maret 2020 pukul 08.0013.00 WIB fasilitator melakukan observasi kegiatan harian di DCRB yang dilakukan oleh pengasuh dan anak-anak. Pada pukul 13.00-15.00 WIB fasilitator secara bergantian melakukan analisis dokumen dengan membaca formulir pendaftaran yang berisi data diri anak berkebutuhan khusus di DCRB, hasil pemeriksaan dari dokter ataupun psikolog sebelumnya, hasil raport, serta catatan pengasuh mengenai perkembangan tiap anak. Selain itu, dilakukan pula wawancara dengan beberapa pengasuh mengenai profil ABK yang ditangani. Pada pukul 15.00-17.00 WIB setelah anakanak DCRB sudah pulang dijemput orangtuanya, diadakanlah pembekalan bagi para pengasuh.

2) Pada hari kedua di hari Sabtu, tanggal 14 Maret 2020 pukul 08.00-09.00 WIB di kantor pengelola DCRB dilakukanlah konseling pada orangtua A, salah satu orangtua anak berkebutuhan khusus DCRB yang dilakukan oleh dua orang fasilitator. Satu orang fasilitator mempraktikkan beragam teknik stimulasi dengan anak-anak DCRB di hadapan seluruh pengasuh. 
Setelah selesai konseling, kedua orang fasilitator bergabung dengan fasilitator yang lain dan turut membantu pengasuh memberikan berbagai contoh teknik stimulasi untuk anakanak. Kegiatan ini berlangsung hingga pukul 12.00 WIB. Setelah makan siang pukul 13.00 WIB dilakukanlah analisis dokumen ABK. Kemudian pukul 14.00 WIB dilakukanlah wawancara terhadap seorang pengasuh oleh salah satu fasilitator. Pada pukul 14.00-15.00 WIB dilakukan konseling oleh dua orang fasilitator terhadap orang tua $\mathrm{K}$, salah satu orangtua anak berkebutuhan khusus DCRB. Dilanjutkan dengan konseling terhadap orang tua G, orang tua anak berkebutuhan khusus lainnya di DCRB pada pukul 15.00-16.00 WIB. Setelah itu dilakukanlah pembekalan kembali untuk para pengasuh pada pukul 16.00-18.00 WIB oleh semua fasilitator.

3) Pada hari ketiga yaitu hari Minggu tanggal 15 Maret 2020 dilakukanlah konseling orang tua $\mathrm{ABK}$ berinisial J oleh dua orang fasilitator pada pukul 08.00-09.00 WIB. Selanjutnya pada pukul 09.00-13.00 WIB berlangsung psikoedukasi berupa seminar untuk seluruh orang tua dan pengasuh yang dilakukan oleh semua fasilitator dengan materi mengenai tahapan perkembangan anak secara umum, ragam anak berkebutuhan khusus dan permasalahannya serta mengenai inklusivitas dan pentingnya pendidikan dan masyarakat inklusi. Selain itu, dilakukan juga role play di mana para orangtua belajar melalui metode bermain peran sebagai orang tua anak. Para orang tua belajar mempraktikkan cara menangani anak yang tantrum dan cara menstimulasi anak dengan menggunakan buku cerita dan berbagai alat permainan. Fasilitator pun memberikan umpan balik. Acara kemudian ditutup dengan diskusi dan tanya jawab serta foto bersama. Setelah itu, para fasilitator pamit undur diri pulang kembali ke Jakarta.

\section{Tahap Akhir}

1. Evaluasi

Evaluasi dilaksanakan selama kegiatan pengembangan kapasitas berlangsung dan ketikakegiatan selesai.Evaluasipelaksanaan kegiatan dilakukan dengan mengisi lembar observasi kegiatan. Sedangkan evaluasi diakhir dilakukan dengan memberikan lembar evaluasi yang diisi oleh pengasuh maupun orangtua segera setelah kegiatan selesai dilaksanakan.

\section{Monitoring}

Setelah kegiatan pengembangan kapasitas ini berlangsung, kemudian dilakukan monitoring dan evaluasi. Fungsi utama monitoring mencakup pemantauan, mendiagnosis kekurangan, pengumpulan data, memperkirakan perubahan lingkungan, dan menggunakan informasi dalam pemecahan masalah. Kegiatan monitoring dilakukan dalam jangka waktu 3 bulan dan 6 bulan kemudian untuk memastikan hasil dapat diterapkan dalam kehidupan sehari-hari. Monitoring juga berguna untuk melihat adakah kendala dalam penerapan hasil sehingga dapat diatasi bersama.

3. Penyusunan Laporan

Laporan disusun segera setelah kegiatan pengembangan kapasitas ini berakhir. Catatan khusus yang ditemukan selama proses pengembangan kapasitas akan langsung didokumentasikan dan diberitahukan kepada pengasuh ataupun orang tua sehingga dapat segera ditindak lanjuti.

\section{HASIL DAN PEMBAHASAN}

Secara umum, kegiatan berjalan dengan lancar. Kegiatan di hari pertama diawali dengan observasi kegiatan harian anak berkebutuhan khusus selama di Daycare Rumah Bahagia. Fasilitator memperhatikan cara berkomunikasi antara pengasuh dengan anak berkebutuhan khusus, cara berinteraksi antara anak berkebutuhan khusus dengan anak-anak lainnya serta bagaimana anak berkebutuhan khusus tersebut menjalani kegiatan keseharian selama di Daycare Rumah Bahagia. 
Dari hasil observasi, tampak masih ada penanganan yang kurang tepat dari pengasuh, terutama saat salah satu anak berkebutuhan khusus tidak mau mengikuti aturan hingga memberikan respon emosional yang berlebihan (tantrum). Terutama pada anak dengan autisme, mereka memperlihatkan perilaku tantrum saat mereka terhalangi untuk melakukan sesuatu yang mereka inginkan. Contohnya saat anak dengan autisme dipaksa untuk makan bersama anak-anak yang lain, padahal ia masih ingin bermain. Anak tersebut pun menunjukkan perilaku tantrum dengan membenturkan kepalanya ke lantai sambil menangis dan berteriak-teriak.

PotegaldanDavidson(2002) mendefinisikan tantrum dengan perilaku seperti tubuh yang kaku dan punggung yang melengkung, menjatuhkan diri ke lantai, berteriak-teriak, menangis, mendorong atau menarik, menginjak, memukul, menendang, melempar, atau melarikan diri. Tantrum berakhir ketika perilaku-perilaku ini berhenti. Anak dengan autisme seringkali mengungkapkan rasa frustasi atau marahnya dengan berperilaku tantrum (Wenar, \& Kerig, 2006).

Berdasarkan penelitian yang dilakukan oleh Khairi dan Sopandi (2020) pada anak-anak autisme di suatu sekolah, upaya yang tepat untuk menangani perilaku temper tantrum adalah dengan mencari penyebabnya, menetapkan aturan yang jelas pada anak, menghindari bertengkar untuk hal sepele, melakukan time out, mencoba berdiskusi saat anak sudah tenang, dan melakukan follow up dengan guru ataupun terapis.

Selain observasi juga dilakukan analisis dokumen yang meliputi membaca berbagai berkas mengenai anak berkebutuhan khusus, yaitu formulir pendaftaran yang berisi data diri anak dan orang tua, hasil rapport atau catatan perkembangan anak yang ditulis oleh pengasuh, berbagai hasil pemeriksaan dari dokter ataupun psikolog sebelumnya.

Fasilitator juga melakukan wawancara terhadap pengelola dan pengasuh Daycare Rumah Bahagia mengenai latar belakang anak berkebutuhan khusus yang dititipkan di Daycare Rumah Bahagia. Pada sesi pembekalan pengasuh di sore hari, fasilitator memberikan materi mengenai pemahaman akan tahapan perkembangan anak, pemahaman akan Anak Berkebutuhan Khusus (ABK), penjelasan materi mengenai ragam anak berkebutuhan khusus serta pemahaman akan masyarakat inklusif dan pendidikan inklusif. Fasilitator juga memberikan masukan mengenai stimulasi yang dapat dilakukan oleh pengasuh untuk mengoptimalkan perkembangan anak berkebutuhan khusus, serta cara yang tepat dalam penanganan menghadapi anak tantrum.

Pada hari kedua, diberikan konseling individual untuk orang tua anak berkebutuhan khusus. Konseling individual dilakukan pada ketiga pasang orang tua anak berkebutuhan khusus. Pada hari ketiga melanjutkan konseling individual untuk satu pasang orang tua anak berkebutuhan khusus. Menurut Geldard dan Geldard (2009) konseling adalah hubungan timbal balik antara konselor dan klien yang bertujuan membantu klien mencari jalan keluar terbaik untuk masalahnya, dengan selalu mempertimbangkan kesejahteraan klien. Tujuan dilakukannya konseling adalah membantu klien untuk berubah dalam cara berpikir dan berperilaku sehingga tidak mengulangi pola berpikir dan berperilaku yang memberikan konsekuensi negatif. Konseling dalam kegiatan ini diharapkan dapat membantu para orangtua sehingga dapat menangani anak mereka yang berkebutuhan khusus secara tepat.

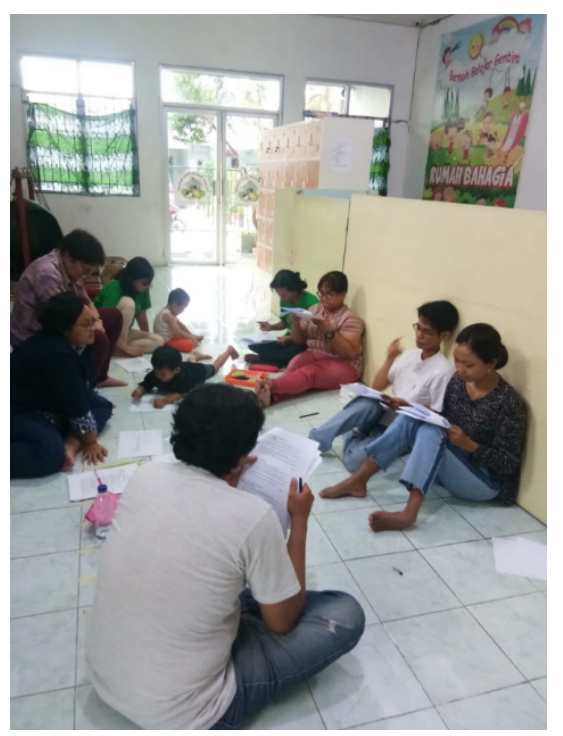

Gambar 2. Kegiatan Pembekalan untuk Pengasuh dan Pengelola Daycare Rumah Bahagia

Warta LPM, Vol. 24, No. 2, April 2021 
Fasilitator mencontohkan berbagai stimulasi yang dapat dilakukan oleh pengasuh ke anak berkebutuhan khusus. Selain itu, fasilitator memberikan keterampilan cara berkomunikasi, cara menangani anak yang sedang tantrum, dan cara penerapan aturan atau disiplin yang positif. Fasilitator memberikan kesempatan bagi pengasuh untuk mempraktikkan berbagai materi yang telah dipelajari, melalui kegiatan simulasi dan role play. Pada sore harinya, pengasuh diberikan alat bantu cara memantau perkembangan anak setiap 3 dan 6 bulan sekali. Hal ini bertujuan agar pengasuh dapat menyusun kurikulum dan Program Pembelajaran Individual (PPI) yang sesuai dengan kebutuhan dan keunikan setiap anak berkebutuhan khusus.

Pada hari ketiga, dilakukan psikoedukasi berupa seminar untuk seluruh orang tua dan pengasuh mengenai peran orang tua dalam mengoptimalkan perkembangan anak berkebutuhan khusus. Pada sesi seminar tersebut, materi disampaikan dengan metode role play, simulasi, serta diskusi dan tanya jawab sehingga orang tua memiliki kesempatan mencoba berbagai teknik stimulasi dan penanganan anak berkebutuhan khusus. Orang tua yang datang pada sesi seminar psikoedukasi berjumlah 17 orang. Sebagian besar datang bersama pasangan masing-masing. Namun ada pula yang datang sendiri. Pengasuh yang datang berjumlah 7 orang dan 2 orang pengelola.

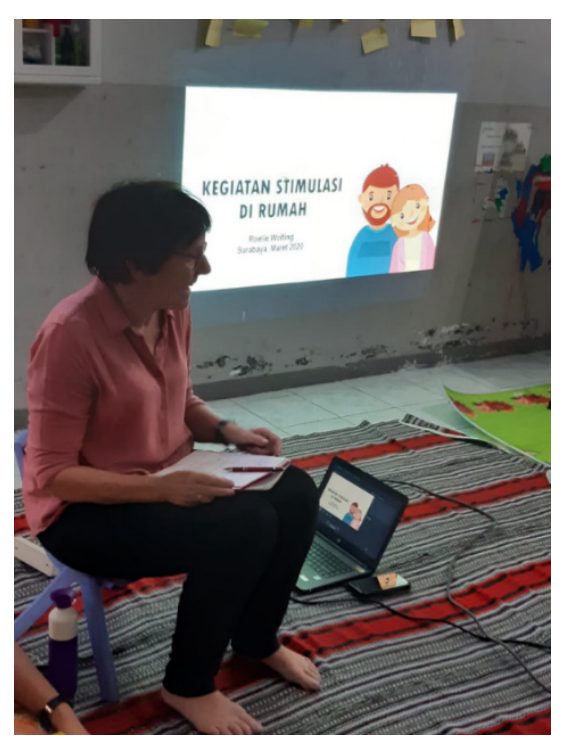

Gambar 3. Kegiatan Psikoedukasi untuk Orangtua, Pengasuh, dan Pengelola Daycare Rumah Bahagia
Padaakhir sesi psikoedukasi pengembangan kapasitas di Daycare Rumah Bahagia, fasilitator memberikan survei tingkat kepuasan kepada partisipan untuk diisi sebagai bahan evaluasi. Hasil survei tingkat kepuasan partisipan tercantum di tabel-tabel dan grafik di bawah ini:

Tabel 1. Tingkat Kepuasan Peserta Orangtua dan Pengasuh terhadap Kegiatan Psikoedukasi

\begin{tabular}{lc}
\hline \multicolumn{1}{c}{ Deskripsi } & $\begin{array}{c}\text { Tingkat } \\
\text { Kepuasan } \\
(\mathbf{0 \% - 1 0 0 \% )}\end{array}$ \\
\hline $\begin{array}{l}\text { Materi yang disampaikan } \\
\text { dapat diaplikasikan ke dalam } \\
\text { kehidupan/pekerjaan sehari- } \\
\text { hari. }\end{array}$ & 91.67 \\
\hline Materi disampaikan dengan jelas & 90.00 \\
\hline $\begin{array}{l}\text { Kegiatan yang diberikan } \\
\text { dikemas dengan menarik dan } \\
\text { menyenangkan }\end{array}$ & 90.00 \\
\hline $\begin{array}{l}\text { Materi yang disampaikan } \\
\text { membantu saya dalam } \\
\text { membantu tumbuh kembang } \\
\text { anak saya }\end{array}$ & 90.00 \\
\hline $\begin{array}{l}\text { Rata-rata tingkat kepuasan } \\
\text { peserta orangtua terhadap } \\
\text { psikoedukasi }\end{array}$ & 89.39 \\
\hline
\end{tabular}

Tabel 2. Rincian Hasil Evaluasi Psikoedukasi menurut Peserta Orangtua dan Pengasuh

\section{Persentase Mean (\%)}

\begin{tabular}{|c|c|c|c|}
\hline \multicolumn{4}{|c|}{ A. Sarana dan Prasarana Kegiatan } \\
\hline 1. & $\begin{array}{l}\text { Ruangan yang } \\
\text { digunakan menunjang } \\
\text { proses belajar }\end{array}$ & 88.33 & 3.53 \\
\hline 2. & $\begin{array}{l}\text { Alat \& Bahan yang } \\
\text { disediakan menunjang } \\
\text { proses belajar } \\
\text { kegiatan }\end{array}$ & 88.33 & 3.53 \\
\hline 3. & $\begin{array}{l}\text { Materi disampaikan } \\
\text { dengan jelas }\end{array}$ & 90.00 & 3.60 \\
\hline 4. & $\begin{array}{l}\text { Materi yang } \\
\text { disampaikan sesuai } \\
\text { dengan apa yang } \\
\text { saya butuhkan } \\
\text { sebagai orang tua dan } \\
\text { pengasuh }\end{array}$ & 85.00 & 3.40 \\
\hline
\end{tabular}




\begin{tabular}{|c|c|c|c|}
\hline 5. & $\begin{array}{l}\text { Kegiatan yang } \\
\text { diberikan dikemas } \\
\text { dengan menarik dan } \\
\text { menyenangkan }\end{array}$ & 90.00 & 3.60 \\
\hline 6. & $\begin{array}{l}\text { Materi yang } \\
\text { disampaikan } \\
\text { membantu saya dalam } \\
\text { membantu tumbuh } \\
\text { kembang anak saya }\end{array}$ & 90.00 & 3.60 \\
\hline 7. & $\begin{array}{l}\text { Penggunaan waktu } \\
\text { dalam kegiatan ini } \\
\text { tergolong cukup bagi } \\
\text { saya }\end{array}$ & 88.33 & 3.53 \\
\hline 8. & $\begin{array}{l}\text { Secara keseluruhan, } \\
\text { saya merasa puas } \\
\text { dengan kegiatan ini }\end{array}$ & 88.33 & 3.53 \\
\hline \multicolumn{4}{|c|}{ B. Fasilitator } \\
\hline 1. & $\begin{array}{l}\text { Fasilitator 1: Reneta } \\
\text { Kristiani }\end{array}$ & 91.67 & 3.67 \\
\hline 2. & $\begin{array}{l}\text { Fasilitator 2: Penny } \\
\text { Handayani }\end{array}$ & 91.67 & 3.67 \\
\hline \multirow[t]{2}{*}{3.} & $\begin{array}{l}\text { Fasilitator 3: Roelie } \\
\text { Wolting }\end{array}$ & 91.67 & 3.67 \\
\hline & Rata-rata & 89.39 & 3.58 \\
\hline
\end{tabular}

Berdasarkan hasil dari kegiatan belajar bersama fasilitator, para pengasuh terlihat memiliki pengetahuan yang lebih mendalam terkait pendampingan dengan anak terutama anak ABK. Seluruh pengasuh telah memahami kegiatan-kegiatan seperti apa yang dapat digunakan untuk mendampingi anak sekaligus melakukan stimulasi yang tepat bagi anak berkebutuhan khusus. Melalui kegiatan ini para pengasuh merasa senang ketika dapat belajar secara langsung melalui role play dan simulasi. Sesuai teori pelatihan Chan (2010) role play membantu orang untuk berlatih dan bereksperimen dengan teknik baru, memberikan mereka wawasan mengenai perilaku diri sendiri dan orang lain. Pengasuh juga merasakan suasana belajar yang santai dan menyenangkan sehingga setiap materi yang disampaikan dapat diterima dan dipahami dengan baik. Pengasuh menjadi lebih terampil dan percaya diri dalam menanganianakberkebutuhan khusus. Pengasuh juga bersyukur mendapatkan alat bantu untuk mengukur dan mengamati perkembangan anak secara rutin setiap 3 dan 6 bulan sekali. Hal ini membuat pengasuh memiliki tolak ukur yang jelas dalam menyusun kurikulum dan Program

\section{EVALUASI PESERTA}

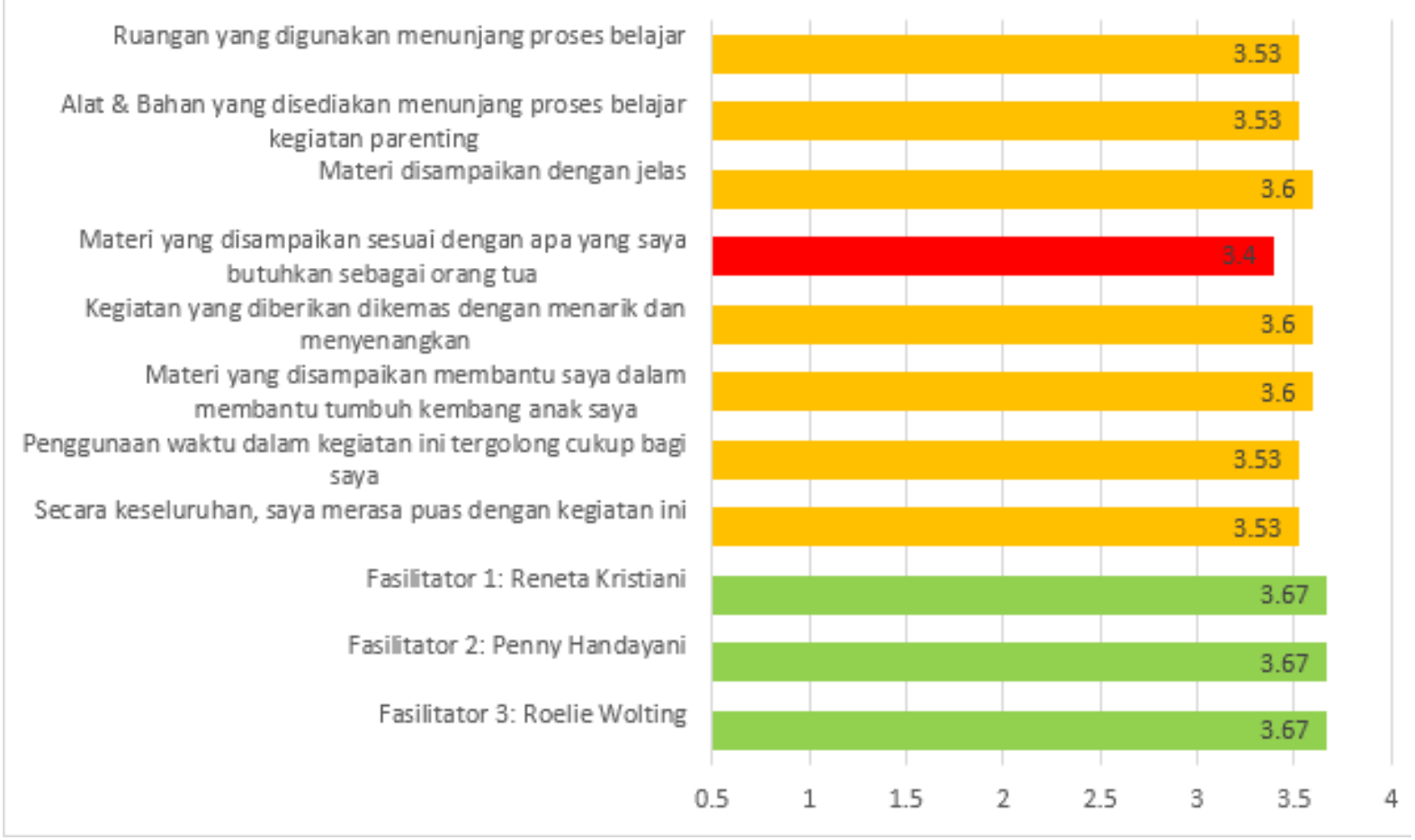

Grafik 1. Evaluasi Tingkat Kepuasan Peserta 
Pembelajaran Individual (PPI) bagi anak berkebutuhan khusus sehingga bisa membuat kegiatan yang tepat.

Secara keseluruhan, tingkat kepuasan peserta terhadap kegiatan ini ialah sebesar 89.39\%, Aspek utama yang dinilai positif oleh peserta ialah terkait fasilitator sebesar $91.67 \%$. Fasilitator yang adalah psikolog dan terapis perilaku dianggap sudah sangat baik dalam menyampaikan materi dengan bahasa yang mudah dipahami serta banyaknya praktik dan simulasi yang membantu orang tua dan pengasuh. Adapun aspek yang perlu ditingkatkan di masa yang akan datang, yaitu orang tua dan pengasuh berharap kegiatan pengembangan kapasitas ini dapat dilakukan secara rutin dengan berbagai materi yang berbeda sesuai dengan kebutuhan orang tua dan pengasuh.

Luaran yang dihasilkan dari kegiatan pengabdian masyarakat ini berupa artikel jurnal serta laporan kegiatan yang berisi mengenai bagaimana pengembangan kapasitas untuk orang tua dan pengasuh anak ABK dari awal tahap persiapan hingga tahap pelaksanaan kegiatan pengembangan kapasitas. Artikel jurnal ini dapat bermanfaat bagi pihak yang ingin mengembangkan kapasitas pengasuh dan orang tua daycare di seluruh Indonesia, terutama dalam penyadaran publik akan isu disabilitas anak.

\section{SIMPULAN}

Kegiatan pengembangan kapasitas ini dapat dikatakan berhasil karena berdasarkan hasil evaluasi, para pengasuh dan orang tua merasakan manfaatnya. Kemampuan pengasuh dan orang tua semakin meningkat dalam menangani anak berkebutuhan khusus. Orang tua dan pengasuh menjadi lebih paham mengenai tahap perkembangan anak secara umum serta penanganan anak berkebutuhan khusus. Orang tua mulai dapat menerima kondisi anaknya yang berkebutuhan khusus. Orang tua dan pengasuh juga semakin terampil dalam memberikan stimulasi pada anak berkebutuhan khusus. Pengasuh pun mendapatkan alat bantu untuk memantau perkembangan anak secara rutin setiap 3 dan 6 bulan sehingga dapat menyusun kurikulum dan program pembelajaran yang sesuai dengan kebutuhan dan keunikan setiap anak. Saran dan rekomendasi dari para orang tua dan pengasuh adalah memperpanjang waktu kegiatan pengembangan kapasitas. Orang tua dan pengasuh berharap sesi diskusi dan tanya jawab diperpanjang waktunya agar dapat memberikan kesempatan bagi masingmasing orang tua dalam menyampaikan permasalahan anak. Orang tua berharap dapat lebih mengetahui kekurangan dan kelebihan diri mereka dalam pengasuhan anak berkebutuhan khusus. Mereka menginginkan kegiatan seperti ini dapat dilakukan secara rutin minimal sebulan sekali. Saran dari fasilitator untuk pengelola daycare sebaiknya menyelenggarakan kegiatan pengembangan kapasitas bagi orang tua dan pengasuh secara rutin, minimal satu bulan sekali agar terjalin komunikasi dan kerjasama yang baik di antara orang tua dan pengasuh. Saran untuk pengabdian masyarakat berikutnya sebaiknya melakukan analisis kebutuhan pengelolaan daycare, memberikan pelatihan pembuatan Program Pembelajaran Individual (PPI) untuk anak berkebutuhan khusus, memberikan pelatihan kepada pengelola daycare dan pengasuh mengenai pendidikan inklusi yang lebih mendalam.

\section{PERSANTUNAN}

Penulis mengucapkan syukur kepada Tuhan Yang Maha Esa atas terlaksananya kegiatan ini. Penulis juga berterima kasih kepada Pusat Pemberdayaan Masyarakat (PPM) UNIKA Atma Jaya yang telah memberikan kesempatan kepada penulis untuk melakukan pengabdian masyarakat di Surabaya. Penulis mengucapkan terima kasih kepada Institut Solidaritas Buruh Surabaya (ISBS) serta Yayasan Rumah Anak Bahagia sebagai pemilik dan pengelola Daycare Rumah Bahagia atas kepercayaannya kepada penulis. Kepada para pengasuh dan orang tua serta anak-anak Daycare Rumah Bahagia, penulis berterima kasih, telah memberikan kesempatan melaksanakan kegiatan ini, terutama anak berkebutuhan khusus atas semangat dan keceriaannya selama berkegiatan bersama penulis. Ucapakan terima kasih juga penulis sampaikan kepada tim fasilitator yang sangat solid sehingga mampu menyelenggarakan kegiatan ini dengan baik. 


\section{REFERENSI}

Arends, R. I. (2012). Learning to Teach ( $9^{\text {th }}$ ed). New York: McGraw-Hill

Chan, J. F. (2010). Training fundamentals. San Francisco: Pfeiffer.

Geldard, D., \& Geldard, K. (2009). Basic Personal Counselling: A Training Manual for Counsellors. Frenchs Forest, Nsw: Pearson Education Australia.

Kementerian Perlindungan Anak dan Pemberdayaan Perempuan (2013). Panduan Penanganan Anak Berkebutuhan Khusus Bagi Pendamping (orang tua, keluarga, dan masyarakat). [online].Diunduh dari https://kemenpppa.go.id/lib/uploads/list/b3401-panduan-penangananabk-bagi-pendamping-_orang-tua-keluarga-dan-masyarakat.pdf diakses Oktober 12, 2020

Khairi, Z., \& Sopandi, A. A. (2020). Upaya Keluarga dalam Menangani Perilaku Temper Tantrum pada Anak Autis Kelas VI di SLB Negeri 1 Padang. Ranah Research: Journal of Multidisciplinary Research and Development, 2(2), 111-116.

Milen, A. (2004) Pegangan Dasar Pengembangan Kapasitas. Diterjemahkan secara bebas. Yogyakarta: Pondok Pustaka Jogja.

Papalia, D.E. \& Martorell, G. (2014). Experience Human Development, 13th Edition. USA: McGraw-Hill International Edition.

Potegal, M., \& Davidson, R. J. (2003). Temper Tantrums in Young Children: 1. Behavioral composition. Journal of Developmental \& Behavioral Pediatrics, 24(3), 140-147.

Pusat Data dan Informasi Kementerian Kesehatan RI (2018). Disabilitas: Hari Disabilitas Internasional 3 Desember 2018. [online]. Diunduh dari www.kemkes.go.id infodatin- disabilitas diakses Maret $20,2020$.

Walsh, J. (2010). Psychoeducation in Mental Health. Chicago: Lyceum Books, Inc

Wenar, C., \& Kerig, P. (2006). Developmental Psychopathology: from Infancy Through Adolescence. New York: Mcgraw-Hill. 